\title{
Enzymatic activity and brine shrimp lethality of venom from the large brown spitting cobra (Naja ashei) and its neutralization by antivenom
}

\author{
Mitchel Otieno Okumu ${ }^{1 *} \mathbb{D}$, James Mucunu Mbaria' ${ }^{1}$, Joseph Kangangi Gikunju², Paul Gichohi Mbuthia ${ }^{3}$, \\ Vincent Odongo Madadi ${ }^{4}$ and Francis Okumu Ochola ${ }^{5}$
}

\begin{abstract}
Objective: Naja ashei is a snake of medical importance in Kenya, Ethiopia, Somalia, Uganda, and Tanzania. Little is known about the enzymatic (snake venom phospholipases $\mathrm{A}_{2} ; \mathrm{VPLA}_{2}$ 's) and toxic (lethal) activities of $\mathrm{N}$. ashei venom and crucially, the safety and capacity of available antivenom to neutralize these effects. This study aimed to determine the enzymatic and toxic activities of $\mathrm{N}$. ashei venom and the capacity of Indian and Mexican manufactured antivenoms to neutralize these effects. The protein content of the venom and the test antivenoms were also evaluated. A 12-point log concentration-response curve $(0.5-22.5 \mu \mathrm{g} / \mathrm{mL})$ was generated on an agarose-egg yolk model to predict the sVPLA 2 activity of the venom. The toxicity profiles of the venom and antivenoms were evaluated in the brine shrimp lethality assay. Lowry's method was used for protein estimation.
\end{abstract}

Results: Low and intermediate concentrations of the venom exhibited similar SVPLA 2 activities. The same was true for concentrations $>15 \mu \mathrm{g} / \mathrm{mL}$. Intermediate and high doses of the venom exhibited similar mortalities in brine shrimp and test antivenoms were generally non-toxic but poorly neutralized svPLA $A_{2}$ activity. Mexican manufactured antivenom had lower protein content but neutralized venom-induced brine shrimp lethality much more effectively than Indian manufactured antivenom.

Keywords: Snake venom phospholipases $A_{2}$, Brine shrimp lethality assay, Snake venom toxicity, Naja ashei, Brine shrimp, Artemia salina, Probit analysis, $\mathrm{LC}_{50}, \mathrm{EC}_{50}, \mathrm{MPC}_{50}$

\section{Introduction}

Snakebite may be the World's biggest hidden health crisis $[1,2]$. Estimates from the World Health Organization suggest that up to 2.7 million people are envenomed by snakes yearly and close to 140,000 die [3]. Non-fatal envenoming may also result in permanent disabilities including blindness, extensive scarring, contractures, restricted mobility, and amputations [4].

\footnotetext{
*Correspondence: mytchan88@gmail.com; drokumitch@students.uonbi.ac.ke ${ }^{1}$ Department of Public Health, Pharmacology, and Toxicology, University of Nairobi, Nairobi, Kenya

Full list of author information is available at the end of the article
}

Naja ashei is a category 1 snake in Kenya, Ethiopia, Somalia, and Uganda and a category 2 snake in Tanzania [5] (Fig. 1). Category 1 snakes are highly venomous and result in high levels of morbidity, disability, or mortality [5]. Category 2 snakes are highly venomous, may cause morbidity, mortality, disability, or death but lack data to implicate them in snakebite [5].

Over the last decade, there has been a lot of interest in $N$. ashei [6-11]. The skull structure [9], mitochondrial DNA [10], composition, antiproliferative, and antibacterial properties of $N$. ashei venom have been reported $[6-8,11]$. However, there has been little focus on the enzymatic, and lethal effects of this venom and the capacity of antivenoms to neutralize them. This study

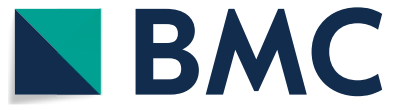

(c) The Author(s) 2020. This article is licensed under a Creative Commons Attribution 4.0 International License, which permits use, sharing, adaptation, distribution and reproduction in any medium or format, as long as you give appropriate credit to the original author(s) and the source, provide a link to the Creative Commons licence, and indicate if changes were made. The images or other third party material in this article are included in the article's Creative Commons licence, unless indicated otherwise in a credit line to the material. If material is not included in the article's Creative Commons licence and your intended use is not permitted by statutory regulation or exceeds the permitted use, you will need to obtain permission directly from the copyright holder. To view a copy of this licence, visit http://creativeco mmons.org/licenses/by/4.0/. The Creative Commons Public Domain Dedication waiver (http://creativecommons.org/publicdomain/ zero/1.0/) applies to the data made available in this article, unless otherwise stated in a credit line to the data. 


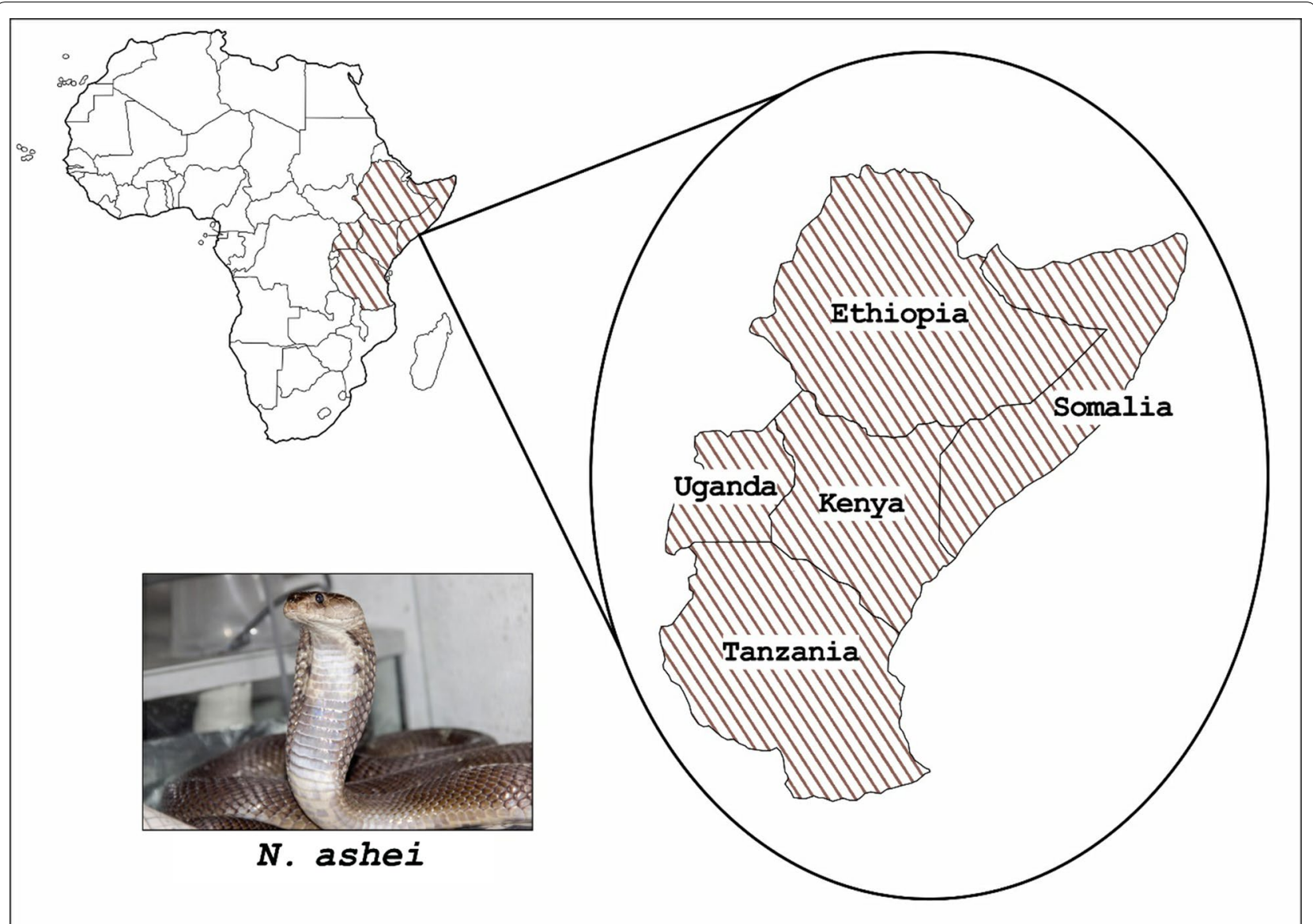

Fig. 1 Distribution of Naja ashei in Africa (Source: Image of Naja ashei adapted from Wikimedia Commons (Lika Ivanova: https://commons.wikim edia.org/wiki/File:NajaAshei.jpg))

aimed to fill this gap by determining the enzymatic and toxic activities of $N$. ashei venom and the capacity of antivenoms to neutralize them.

\section{Main text}

\section{Materials and methods}

\section{Snake venom and antivenom}

Venom was extracted from specimens of wild-caught $N$. ashei maintained at the Bioken Snake Farm in Kenya (Table S1); https://doi.org/10.6084/m9.figshare.12562 055.v1. Collected venom was snap-frozen and stored at $-20{ }^{\circ} \mathrm{C}$. Reconstitution was done in phosphate-buffered saline (PBS) at the time of use. Antivenoms were sourced from hospitals in Kisumu County, Kenya. See (Table S2); https://doi.org/10.6084/m9.figshare.12562055.v1.

\section{Animals (brine shrimp)}

Brine shrimp eggs were commercially sourced from yourfishstuff (Borough of Lebanon, New Jersey, USA; Batch number; X001M8M5IZ). They were hatched at the Department of Public Health, Pharmacology, and
Toxicology, University of Nairobi, and brine shrimp larvae were used for experiments.

\section{Protein content determination of the venom and antivenoms}

Lowry's method was used [12]. An eight-point calibration curve $(0.05-2 \mathrm{mg} / \mathrm{mL})$ was developed using bovine serum albumin (BSA) as standard. Absorbance was recorded at $660 \mathrm{~nm}$ and the protein content of samples was inferred from the standard curve. See https://doi. org/10.6084/m9.figshare.12562136.v2.

\section{sVPLA $A_{2}$ activity of venom}

The methods of Haberman and Hardt and Felix Silva et al. were used $[13,14]$. Wells were made on sterile petri dishes containing agarose egg-yolk media $(1: 3 \mathrm{v} / \mathrm{v}$ egg yolk: $\mathrm{PBS}+125 \mu \mathrm{L}$ of $0.1 \mathrm{mM} \mathrm{CaCl}$ ) prepared in a laminar flow cabinet. $10 \mu \mathrm{L}$ of previously incubated $\left(37^{\circ} \mathrm{C}, 1 \mathrm{~h}\right)$ and serially diluted venom was discharged into the wells and incubated for $24 \mathrm{~h}$ at $50{ }^{\circ} \mathrm{C}$. Carbol Fuchsin was used to visualize the halos which were measured by Vernier calipers. PBS was used as a negative 
control. Triplicate determinations were made and the least amount of venom required to elicit a $50 \%$ svPLA $_{2}$ response $\left(\mathrm{MPC}_{50}\right)$ was determined by regression analysis.

Neutralization of the SvPLA $A_{2}$ activity of venom by antivenom The method of Iwanaga and Suzuki 1979 was used [15]. $10 \mu \mathrm{L}$ of a $2 \mathrm{MPC}_{50}$ dose of venom was mixed with $20 \mu \mathrm{L}$ of various doses of test antivenoms $(25-400 \mu \mathrm{g} /$ $\mathrm{mL}$ ) in 96-well plates for $5 \mathrm{~min}$ on a microplate shaker. The plate was incubated at $37{ }^{\circ} \mathrm{C}$ for $20 \mathrm{~min}, 200 \mu \mathrm{L}$ of the substrate $(1.1 \%$ egg yolk suspension in $0.1 \mathrm{M}$ PBS adjusted to $\mathrm{pH} 8.1$ and $125 \mu \mathrm{L} 0.2 \mathrm{mM} \mathrm{CaCl}_{2}$ ) was added to all wells, incubated at $37{ }^{\circ} \mathrm{C}$ and the change in absorbance of the substrate ( 0 to $30 \mathrm{~min}$ ) was determined spectrophotometrically at $620 \mathrm{~nm}$ [15]. Triplicate determinations were made and the least amount of antivenom required to reduce svPLA $_{2}$ activity by $50 \%$ $\left(\mathrm{EC}_{50}\right)$ was determined by regression analysis.

\section{Determination of the brine shrimp lethality of venom, antivenom, and controls}

The method of Meyer et al. was used [16]. Ten, 48-h old brine shrimp larvae were transferred from a hatching trough to $5 \mathrm{~mL}$ sample vials. Aliquots $(5,50$ and $500 \mu \mathrm{L})$ of $5 \mathrm{mg} / \mathrm{mL}$ stock solutions of the samples (venom/ antivenom) were pipetted into the vials and made up to the mark using $38.5 \% \mathrm{w} / \mathrm{v}$ marine salt solution to make 10, 100, and $1000 \mu \mathrm{g} / \mathrm{mL}$ sample concentrations respectively. PBS and vincristine sulphate were used as negative and positive controls respectively. Quintuple determinations were made and surviving larvae were counted after 24,48 , and $72 \mathrm{~h}$. $\mathrm{LC}_{50}$ s of samples were calculated by probit analysis. $\mathrm{LC}_{50}$ was defined as the least concentration of samples which resulted in 50\% mortality of brine shrimp [17].

\section{Neutralization of venom-induced lethality}

The WHO (World Health Organization) protocol on venom neutralization by antivenoms was used with modifications [5]. Varying doses of the antivenoms (25$400 \mu \mathrm{L}$ of $100 \mathrm{mg} / \mathrm{mL}$ ) were mixed with a $2 \mathrm{LC}_{50}$ dose of venom. The venom/antivenom mixtures were incubated at $37{ }^{\circ} \mathrm{C}$ for $30 \mathrm{~min}$, added to vials containing brine shrimp larvae and surviving larvae were counted after 24 , 48 , and $72 \mathrm{~h}$. The median effective concentration $\left(\mathrm{EC}_{50}\right)$ of the antivenoms was determined by regression analysis and was defined as the minimum amount of antivenom (in $\mu \mathrm{L}$ ) that was required to neutralize $1 \mathrm{mg}$ of venom [5].

\section{Statistical analysis}

Venom concentrations were converted to $\log _{10}$ ( $\mathrm{x}$-axis) and mean responses were converted to percentages (y-axis). The concentration of venom responsible for $50 \%$ svPLA 2 activity $\left(\mathrm{MPC}_{50}\right)$ was predicted by regression analysis (SPSS v20). Mortalities were converted to probits and regressed against the log concentration of venom (MS Excel 2013) [18, 19]. Analysis of variance and Tukey's post hoc test $(p<0.05)$ was used to evaluate dose-dependent differences in svPLA $A_{2}$ activity and brine shrimp lethality. Meyer's and Clarkson's criteria were used to infer the toxicity of substances tested in the brine shrimp lethality assay $[16,20]$.

\section{Results}

There was no significant difference $(p>0.05)$ in the svPLA $_{2}$ activity of venom doses ranging from 0.5 to $8 \mu \mathrm{g} / \mathrm{mL}$ (Table 1). See https://doi.org/10.6084/m9.figsh

Table 1 The dose-response relationship of svPLA 2 in Naja ashei venom

\begin{tabular}{|c|c|c|c|}
\hline Concentration of venom $(\mu \mathrm{g} / \mathrm{mL})$ & $\log _{10}$ concentration & Mean $(S D)(n=6)$ & $\%$ svPLA 2 activity \\
\hline 0 & - & $0.0(0.0)$ & $0.0(0.0)$ \\
\hline 0.5 & -0.3010 & $9.5(0.5)^{\mathrm{a}}$ & $49.3(3.3)^{\mathrm{a}}$ \\
\hline 1.0 & 0.0000 & $10.0(0.6)^{\mathrm{a}}$ & $52.0(5.6)^{a}$ \\
\hline 2.0 & 0.3010 & $11.8(1.6)^{\mathrm{ab}}$ & $61.5(8.9)^{\mathrm{ab}}$ \\
\hline 4.0 & 0.6021 & $12.2(1.0)^{\mathrm{ab}}$ & $63.3(8.1)^{\mathrm{ab}}$ \\
\hline 8.0 & 0.9031 & $12.0(0.9)^{\mathrm{ab}}$ & $62.5(8.3)^{a b}$ \\
\hline 10.0 & 1.0000 & $13.8(1.6)^{b}$ & $72.0(10.6)^{b c}$ \\
\hline 12.5 & 1.0970 & $14.4(2.4)^{\mathrm{bc}}$ & $75.4(17.2)^{\mathrm{bcd}}$ \\
\hline 15.0 & 1.1760 & $17.1(2.1)^{\mathrm{cd}}$ & $88.6(10.4)^{\text {cde }}$ \\
\hline 17.5 & 1.2430 & $18.8(1.5)^{d}$ & $97.0(3.4)^{\mathrm{e}}$ \\
\hline 20.0 & 1.3010 & $16.7(1.2)^{\mathrm{cd}}$ & $86.3(3.7)^{\mathrm{cde}}$ \\
\hline 22.5 & 1.3522 & $17.7(0.4)^{d}$ & $91.8(7.6)^{\mathrm{de}}$ \\
\hline
\end{tabular}

Means with different superscripts along the columns are significantly different from each other at $p<0.05$ (ANOVA and Bonferroni post hoc test)

svPLA $A_{2}$ snake venom phospholipase $\mathrm{A}_{2}$ 
are.12562163.v2. The same was true for doses $>15 \mu \mathrm{g} / \mathrm{mL}$ (Table 1). There was a positive linear relationship between the log concentration of venom and the \%svPLA ${ }_{2}$ activity (Figure S1); https://doi.org/10.6084/m9.figshare.12562 175.v3. The correlation was significant; $r(65)=0.804$, $p<0.05$, regression equation was $\hat{\mathrm{y}}=26.339 \mathrm{x}+51.906$, and $r^{2}=0.646$; that is, $64.6 \%$ of the variance in the $\% \mathrm{svPLA}_{2}$ activity was predictable from the log concentration of venom. Based on this regression model, the $\mathrm{MPC}_{50}$ was found to be $0.847 \mu \mathrm{g} / \mathrm{mL}$.

There was a negative linear relationship between the log concentration of the venom + antivenom I mixture and \%svPLA ${ }_{2}$ activity (Figure S2); https://doi.org/10.6084/ m9.figshare.12570617.v1. The correlation was significant $\mathrm{r}(14)=0.669, p=0.006$ and regression equation was $\hat{y}=-44.792 x+154.164$. Based on this regression model, $1 \mathrm{~mL}$ of antivenom I neutralized $0.08 \mu \mathrm{g}$ of svPLA $_{2}$.

There was a negative linear relationship between the log concentration of the venom + antivenom II mixture and \%svPLA ${ }_{2}$ activity (Figure S3); https://doi.org/10.6084/ m9.figshare.12571100.v1. The correlation was significant $\mathrm{r}(14)=0.772, p=0.001$ and regression equation was $\hat{y}=-44.706 x+162.226$. Based on this regression model $1 \mathrm{ml}$ of antivenom II neutralized $0.05 \mu \mathrm{g}$ of svPLA ${ }_{2}$.

Test antivenoms were generally non-toxic (Table 2), $N$. ashei venom was more toxic than vincristine sulphate (positive control) after $24 \mathrm{~h}$ but vincristine sulphate was more toxic than venom after 48 and 72-h (Table 2). See also https://doi.org/10.6084/m9.figshare.12571547.v1, https://doi.org/10.6084/m9.figshare.12571283.v1, and https://doi.org/10.6084/m9.figshare.12571283.v3. There was no significant difference $(p>0.05)$ in the \% mortality of brine shrimps exposed to $100 \mu \mathrm{g} / \mathrm{mL}$ or $1000 \mu \mathrm{g} / \mathrm{mL}$ of venom after 24,48 , and $72 \mathrm{~h}$. See https://doi.org/10.6084/ m9.figshare.12562199.v2.

One milliliter of antivenom II neutralized $0.207 \mathrm{mg}$ of venom in the brine shrimp lethality assay but antivenom I was ineffective. See https://doi.org/10.6084/m9.figsh are.12570620.v2. The mean protein content of the venoms and antivenoms was significantly different from each other. See https://doi.org/10.6084/m9.figsh are.12573425.v1.

\section{Discussion}

Naja ashei venom is yet to be included in immunizing mixtures of commercially available antivenom. In this study, we have demonstrated that Mexican and Indian manufactured antivenoms poorly neutralized the svPLA activity of this venom. We have also established that only the Mexican manufactured antivenom was effective in neutralizing the toxic effects of this venom. These observations highlight the limited efficacy of imported antivenoms in neutralizing key toxins in the venom of a snake associated with many bites in East Africa [5]. The clamor for locally manufactured antivenoms seems justified [21].

In the context of African spitting cobras, Indian manufactured antivenom is indicated for Naja nigricollis and Naja haje envenomation while the Mexican manufactured antivenom is indicated for Naja nigricollis, Naja haje, Naja pallida, Naja nubiae and Naja katiensis [22]. Therefore, it may be inferred that the cross-neutralization of toxic proteins in $N$. ashei venom by Mexican manufactured antivenom was because the

Table 2 The brine shrimp cytotoxicity profile of Naja ashei venom, two commercial antivenoms, and vincristine sulphate (standard cytotoxic agent)

\begin{tabular}{|c|c|c|c|c|c|c|c|}
\hline \multirow[t]{2}{*}{ Sample } & \multirow{2}{*}{$\begin{array}{l}\text { Duration } \\
\text { of exposure }\end{array}$} & \multicolumn{3}{|c|}{ Mortality per test dose } & \multirow[t]{2}{*}{$\mathrm{LC}_{50}(\mu \mathrm{g} / \mathrm{ml})$} & \multicolumn{2}{|l|}{ Toxicity } \\
\hline & & $10 \mu \mathrm{g} / \mathrm{ml}$ & $100 \mu \mathrm{g} / \mathrm{ml}$ & $1000 \mu \mathrm{g} / \mathrm{ml}$ & & $\begin{array}{l}\text { Meyer's toxicity } \\
\text { index [16] }\end{array}$ & $\begin{array}{l}\text { Clarkson's } \\
\text { toxicity index } \\
{[20]}\end{array}$ \\
\hline \multirow{3}{*}{$\begin{array}{l}\text { Vincristine sulphate } \\
\text { (positive control) }\end{array}$} & 24 & 0 & 30 & 46 & 171.83 & Toxic & Highly toxic \\
\hline & 48 & 35 & 50 & 50 & 2.10 & Toxic & Highly toxic \\
\hline & 72 & 50 & 50 & 50 & All died & Toxic & Highly toxic \\
\hline \multirow[t]{3}{*}{ Antivenom I } & 24 & 0 & 0 & 0 & No mortality & Non toxic & Non toxic \\
\hline & 48 & 11 & 8 & 29 & 2346.23 & Non toxic & Non toxic \\
\hline & 72 & 13 & 9 & 29 & 5268.05 & Non toxic & Non toxic \\
\hline \multirow[t]{3}{*}{ Antivenom II } & 24 & 0 & 0 & 0 & No mortality & Non toxic & Non toxic \\
\hline & 48 & 11 & 8 & 13 & $599,484,250.30$ & Non toxic & Non toxic \\
\hline & 72 & 12 & 11 & 17 & 1622.89 & Non toxic & Non toxic \\
\hline \multirow[t]{3}{*}{ Naja ashei venom } & 24 & 0 & 48 & 50 & 63.02 & Toxic & Highly toxic \\
\hline & 48 & 26 & 50 & 50 & 4.73 & Toxic & Highly toxic \\
\hline & 72 & 40 & 50 & 50 & 0.15 & Toxic & Highly toxic \\
\hline
\end{tabular}


toxicity profile of $N$. ashei venom may be similar to the profile in Naja pallida, Naja nubiae, and Naja katiensis venoms but dissimilar to Naja nigricollis and Naja haje venoms.

How can the pharmacological findings in this study be explained by what is known about the composition of $N$. ashei venom? Hus and colleagues indicated that the most abundant proteins in $N$. ashei venom were cytotoxins (3FTxs; three-finger toxins) and svPLA $_{2}$ 's [8]. Other venom proteins include $5^{\prime} \mathrm{N}$-Snake venom 5'-nucleotidase; SVMPs-snake venom metalloproteinases; CRISPs-cysteine-rich venom proteins; CVF-cobra venom factor; and VNGF-venom nerve growth factor [8]. svPLA ${ }_{2}$ 's may be acidic or basic and are divided into groups IA, IIA, and IIB [23]. The fact that this study used a $\mathrm{pH}$ of 8.1 to run the agarose-egg yolk assay strongly suggests that the observed svPLA activity was basic. This corroborates the findings of a previous study which reported that a majority of $N$. ashei venom proteins were of low molecular weight and basic [8]. Group IA svPLA 2 's are primarily found in elapids, although some have been reported in colubrids [23]. Group IIA and IIB svPLA's are exclusively found in viperids [23]. Since $N$. ashei is an elapid, the svPLA 2 activity observed was most likely of the Group IA variety.

Naja ashei venom exhibited strong cytotoxic action in the brine shrimp lethality assay relative to vincristine sulphate (a standard cytotoxic). It is important to note that the brine shrimp lethality assay is a good predictor of cytotoxicity and has been widely used to reliably detect this phenomenon in the venom of the sea snake; Enhydrina schistosa [24], and in several venomous fish [25-28], snails [29-31], toads [32] and bees [33]. The dose and time-dependent brine-shrimp lethality observed may be a direct consequence of the non-enzymatic effects of cytotoxins i.e. paralysis, $\mathrm{Ca}^{2+}$ toxicity, and cell death [34]. However, it is unlikely that this observation was not supported by the enzymatic action of the basic Group IA svPLA ${ }_{2}$ 's which have been known to cause organelle toxicity, hydrolysis of the lipid environments of cell membranes, and mitochondrial membrane disruption of the respiratory muscle [34-36]. An important finding in this study was that the concentration of $N$. ashei venom was not the only predictor of svPLA ${ }_{2}$ activity. This raises a pertinent question: what other factors may be involved in predicting this activity? It was also observed that low and intermediate doses of $N$. ashei venom produced similar svPLA $\mathrm{A}_{2}$ activities and there was no difference in the brine shrimp mortalities caused by intermediate and high doses of the venom. This may suggest that the activities of these toxins remain fairly constant within a narrow range of venom doses.
It was established that both antivenoms were safe in brine shrimp. The evaluation of the safety profile of the test antivenoms was important because (i) snake antivenoms may cause both acute (anaphylactic/ pyrogenic) and delayed (serum sickness) toxic manifestations in human envenomation [37], and (ii) the safety profile was key in informing the selection of antivenom aliquots to be used in the neutralization assay.

Based on protein estimation by Lowry's method, it was established that Indian manufactured antivenom had a higher protein content than Mexican manufactured antivenom but was ineffective in neutralizing the toxic effects of $N$. ashei venom. Because both antivenoms are made up of immunoglobulin-binding fragments; $F(a b)$ 's [22] and given the fact that Lowry's method largely reports the aromatic acid (tyrosine and tryptophan) composition of proteins [38], it may be argued that these amino acids may not be involved in the recognition and neutralization of toxic venom proteins in $N$. ashei venom.

\section{Conclusions}

The svPLA ${ }_{2}$ activity and toxicity of $N$. ashei venom remain fairly constant within a narrow range of venom doses. Commercially available antivenoms are generally safe but have limited efficacy in neutralizing the svPLA ${ }_{2}$ activity of $N$. ashei venom. Moreover, only Mexican manufactured antivenom cross-neutralizes toxic venom proteins in $N$. ashei venom. We recommend studies on the activities of other toxins in this venom and their neutralization by antivenom.

\section{Limitations}

Snake venom is a complex mixture of toxins. This study only evaluated the snake venom phospholipases $A_{2}$ activity and brine shrimp lethality of $N$. ashei venom. To fully understand the capacity of antivenoms to neutralize $N$. ashei venom, it may be necessary to evaluate other toxins in this venom.

\section{Abbreviations \\ svPLA $A_{2}$ : Snake venom phospholipase $A_{2} ; B S L A$ : Brine shrimp lethality assay; $\mathrm{LC}_{50}$ : Lethal concentration responsible for $50 \%$ mortality; $\mathrm{MPC}_{50}$ : The minimum phospholipase concentration responsible for $50 \%$ response; $\mathrm{EC}_{50}$ : The least amount of antivenom (in $\mu \mathrm{L}$ ) required to neutralize $1 \mathrm{mg}$ of venom; DNA: Deoxyribonucleic acid; BSA: Bovine Serum Albumin; UV: Ultraviolet; mM: Millimole; $v / \mathrm{v}$ : Volume by volume; $\mu \mathrm{L}$ : Microliter; $\mu \mathrm{g} / \mathrm{mL}$ : Microgram per milliliter; mm: Millimeter; ELISA: Enzyme-linked Immunosorbent assay; PBS: Phosphate-buffered saline; $\mathrm{CaCl}_{2}$ : Calcium chloride; WHO: World Health Organization; $\mathrm{mg} / \mathrm{mL}$ : Milligram per milliliter; $\mathrm{r}^{2}$ : Coefficient of determination; $\mathrm{LD}_{50}$ : Median lethal dose.}

\section{Acknowledgements}

The authors would like to acknowledge Ms. Claire Taylor and Mr. Boniface Momanyi of the Bioken Snake Farm (Watamu, Kenya) for providing the venom samples. We would also like to thank Ms. Vivian of the Department of Animal Physiology, the University of Nairobi who helped us in freeze-drying 
the venom samples and Dr. Nduhiu, Mr. Mainga, Mr. Maloba, Mr. Nderitu, Mr. Antony (BVM student) and Mr. Bett of the Department of Public Health, Pharmacology and Toxicology for their assistance in the phospholipase and brine shrimp lethality assays. Special gratitude to Dr. Nelson Odhiambo and Edna Opiyo of the Nyakach Sub County Hospital for providing the antivenom samples that were used in this study. We also wish to thank Dr. Joshua Onono and Mr. Duke Gekonge for their assistance in statistical analysis.

\section{Authors' contributions}

Conceptualization: MO, FO, and JG; data curation: all authors; formal analysis: $\mathrm{MO}$; investigation: all authors; methodology: $\mathrm{MO}$; project administration: $\mathrm{MO}$ and FO, resources; all authors; software: MO; supervision; JM, JG, PM, and VO; validation: $\mathrm{FO}, \mathrm{JM}, \mathrm{JG}, \mathrm{PM}$, and $\mathrm{VO}$; visualization: $\mathrm{MO}$; writing original draft: $\mathrm{MO}$ : writing review and editing: all authors. All authors read and approved the final manuscript.

\section{Funding}

This study did not receive any external funding.

\section{Availability of data and materials}

All data generated or analyzed during this study are included in this published article. [And its additional information files below]. Information on the snakes whose venom was used in this study (Table S1); https://doi.org/10.6084/ m9.figshare.12562055.v1. Details on the snake antivenom used in this study (Table S2); https://doi.org/10.6084/m9.figshare.12562055.v1. Raw data of the absorbance values ( $660 \mathrm{~nm}$ ) of different concentrations of bovine serum albumin (protein standard), Naja ashei venom, and antivenom; https://doi. org/10.6084/m9.figshare.12562136.v2. The data output from the analysis of variance (+Tukey's post hoc test) to determine dose-dependent differences in the SVPLA 2 activity of Naja ashei venom; https://doi.org/10.6084/m9.figsh are.12562163.v2. The data output from the simple linear regression analysis to determine the \% vPLA 2 activity of different concentrations of Naja ashei venom (Figure S1); https://doi.org/10.6084/m9.figshare.12562175.v3. The data output from the simple linear regression to determine the capacity of antivenom I and II to neutralize the svPLA activity of Naja ashei venom (Figure S2), and (Figure S3);https://doi.org/10.6084/m9.figshare.12570617.v1, https://doi. org/10.6084/m9.figshare.12571100.v1. The data output from probit regression analysis to determine the toxicity of Naja ashei venom, and vincristine and the safety of antivenom in brine shrimp;https://doi.org/10.6084/m9.figsh are.12571547.v1, https://doi.org/10.6084/m9.figshare.12571283.v1, and https ://doi.org/10.6084/m9.figshare.12571283.v3. The data output from analysis of variance (+Tukey's post hoc test) to determine dose-dependent differences in Naja ashei venom-induced brine shrimp lethality; https://doi.org/10.6084/ m9.figshare.12562199.v2. The data output from simple linear regression to determine the capacity of antivenom to neutralize Naja ashei venom-induced brine shrimp lethality https://doi.org/10.6084/m9.figshare.12570620.v2. The data output from analysis of variance (+Tukey's post hoc test) to determine the differences in the mean protein content of Naja ashei venom and antivenom I and II https://doi.org/10.6084/m9.figshare.12573425.v1.

\section{Ethics approval and consent to participate}

This study was approved by the Biosafety, Animal Use, and Ethics Committee of the Faculty of Veterinary Medicine, University of Nairobi. REF BAUEC/2019/220 issued on $24^{\text {th }}$ April 2019. The animals (brine shrimps; Artemia salina) used in this study were commercially sourced thus the owner's consent was not required.

\section{Consent for publication}

Not applicable.

\section{Competing interests}

The authors declares that they have no competing interests.

\section{Author details}

${ }^{1}$ Department of Public Health, Pharmacology, and Toxicology, University of Nairobi, Nairobi, Kenya. ${ }^{2}$ Department of Medical Laboratory Science, Jomo Kenyatta University of Agriculture and Technology, Nairobi, Kenya. ${ }^{3}$ Department of Veterinary Pathology, Microbiology, and Parasitology, University of Nairobi, Nairobi, Kenya. ${ }^{4}$ Department of Chemistry, University of Nairobi, Nairobi, Kenya. ${ }^{5}$ Department of Pharmacology and Toxicology, Moi University, Eldoret, Kenya.
Received: 28 March 2020 Accepted: 30 June 2020

Published online: 06 July 2020

\section{References}

1. Snakebite: "The world's biggest hidden health crisis" — medical brief. https ://www.medicalbrief.co.za/archives/snakebite-worlds-biggest-hidde n-health-crisis/. Accessed 22 May 2020.

2. The Antivenom Crisis in Africa. http://www.snakebiteinitiative.org/?page id=696. Accessed 14 July 2018.

3. Gutiérrez JM, Calvete JJ, Habib AG, Harrison RA, Williams DJ, Warrell DA. Snakebite envenoming. Nat Rev Dis Primers. 2017;3:17063. https://doi. org/10.1038/nrdp.2017.63.

4. Branche C, Ozanne-Smith J, Oyebite K, Hyder AA. World report on child injury prevention. Geneva: World Health Organization; 2008.

5. WHO. Post-ECBS version. Expert committee on biological standardization Geneva, 17 to 21 October 2016. WHO guidelines for the production, control, and regulation of snake antivenom immunoglobulins. World Health Organization'2016; pp. 1-138.

6. Petrilla V, Tomečková V, Komanický V, Lichardusová L, Šutorová M, Petrillová M, et al. Fluorescent profiling of venom-selected cobra species. Spectrosc Lett. 2014;47:1-5.

7. Bocian A, Ciszkowicz E, Hus KK, Buczkowicz J, Lecka-Szlachta K, Pietrowska M, et al. Antimicrobial activity of protein fraction from Naja ashei venom against Staphylococcus epidermidis. Molecules. 2020;25:293.

8. Hus KK, Buczkowicz J, Petrilla V, Petrillová M, Łyskowski A, Legáth J, et al. First Look at the Venom of Naja ashei. Molecules. 2018;23:609.

9. Andrejcakova Z, Vlckova R. Comparisons of the African Cobras using electrophoretical analysis of venom and their morphology. Int Res J Nat Appl Sci. 2015;4:58-68.

10. Wüster W, Broadley DG. Get an eyeful of this: a new species of giant spitting cobra from eastern and north-eastern Africa (Squamata: Serpentes: Elapidae: Naja). Zootaxa. 2007;68:51-68.

11. Antolikova NR, Kello M, Zigova M, Tischlerova V, Petrilla V, Pirnik Z, et al. Naja ashei venom induces mitochondria-mediated apoptosis in human colorectal cancer cells. Acta Biochim Pol. 2019;66:207-13.

12. Waterborg JH. The lowry method for protein quantitation. In: Walker JM, editor. The protein protocols handbook. 3rd ed. New Jersey, USA: Humana press; 2009. p. 7-10.

13. Habermann E, Hardt KL. A sensitive and specific plate test for the quantitation of phospholipases. Anal Biochem. 1972;50:163-73.

14. Felix-Silva J, Souza T, Menezes YAS, Cabral B, Camara RBG, Silva-Junior AA, et al. Aqueous leaf extract of Jatropha gossypiifolia L. (Euphorbiaceae) inhibits enzymatic and biological actions of Bothrops jararaca snake venom. PLOS ONE. 2014;9:e104952.

15. Iwanaga S, Suzuki T. Enzymes in snake venom. In: Suzuki T, editor. Snake venoms. Berlin: Springer; 1979. p. 61-158.

16. Meyer BN, Ferrigni NR, Putnam JE, Jacobsen LB, Nichols DEJ, McLaughlin JL. Brine shrimp: a convenient general bioassay for active plant constituents. Planta Medica. 1982;45:31-4.

17. Parra AL, Yhebra RS, Sardiñas IG, Buela LI. Comparative study of the assay of Artemia salina $\mathrm{L}$. and the estimate of the median lethal dose (LD50 value) in mice, to determine oral acute toxicity of plant extracts. Phytomedicine. 2001;8:395-400.

18. Bliss Cl. The calculation of the dosage-mortality curve. Ann Appl Biol. 1935;22:134-67.

19. Finney DJ. Probit analysis: statistical treatment of the sigmoid response curve. Cambridge: Cambridge University Press; 1952.

20. Clarkson C, Maharaj VJ, Crouch NR, Grace OM, Pillay P, Matsabisa MG, et al. In vitro antiplasmodial activity of medicinal plants native to or naturalized in South Africa. J Ethnopharmacol. 2004;92:177-91.

21. About Us | Kenya Snakebite Research and Intervention Centre. https:// ksric-asrg.org/about-us/. Accessed 1 June 2020.

22. Harrison RA, Oluoch GO, Ainsworth S, Alsolaiss J, Bolton F, Arias A-S, et al. Preclinical antivenom-efficacy testing reveals potentially disturbing deficiencies of snakebite treatment capability in East Africa. PLoS Negl Trop Dis. 2017;11:e0005969.

23. Pucca MB, Ahmadi S, Cerni FA, Ledsgaard L, Sørensen CV, McGeoghan FTS, et al. Unity makes strength: exploring intraspecies and interspecies 
toxin synergism between phospholipases A2 and cytotoxins. Front Pharmacol. 2020;11:611.

24. Damotharan P, Veeruraj A, Arumugam M, Balasubramanian T. Isolation and characterization of biologically active venom protein from sea snake Enhydrina schistosa. J Biochem Mol Toxicol. 2015;29:140-7.

25. Veeruraj A, Pugazhvendan SR, Ajithkumar TT, Arumugam M. Isolation and identification of cytotoxic and biological active toxin from the pufferfish Arothron stellatus. Toxicol Res. 2016;32:215-23.

26. Hahn ST, O'Connor JM. An investigation of the biological activity of bullrout (Notesthes robusta) venom. Toxicon. 2000;38:79-89.

27. Abirami P, Arumugam M, Giji S, Nagarajan S. Bio-prospecting of catfish sting venom Arius maculatus available along South East coast of India. Int J Pharm Pharm Sci. 2014;6:110-5.

28. Nair MSR, Cheung P, Leong I, Ruggieri GD. A non-proteinaceous toxin from the venomous spines of the lionfish Pterois volitans (Linnaeus). Toxicon. 1985;23:525-7.

29. Bajo L, Tan R, Lagas KF, Perocho RCJ, Gomez E. Biological characterization of Conus striatus venom for medical applications. Sci Int Lahore. 2017;2017(29):1277-81.

30. Wu X, Shao X, Guo Z-Y, Chi C-W. Identification of neuropeptide Y-like conopeptides from the venom of Conus betulinus. Acta Biochim Biophys Sin. 2010;42:502-5.

31. Kumari A, Ameri S, Ravikrishna P, Dhayalan A, Kamala-Kannan S, Selvankumar T, et al. Isolation and characterization of conotoxin protein from Conus inscriptus and its potential anticancer activity against cervical cancer (HeLa-HPV 16 associated) cell lines. Int J Peptide Res Ther. 2019:26:1051-9.
32. Xiao J, Zhao X, Zhong W-T, Jiao F-R, Wang X-L, Ma L, et al. Bufadienolides from the venom of bufo Bufo gargarizans and their enzyme inhibition activities and brine shrimp lethality. Nat Prod Commun. 2018. https://doi. org/10.1177/1934578X1801300710.

33. Abrantes AF, da Rocha TC, de Lima ABS, Cavalcanti MT. Honeybee venom: influence of collection on quality and cytotoxicity. Ciência Rural. 2017. https://doi.org/10.1590/0103-8478cr20160486.

34. Bickler PE. Amplification of snake venom toxicity by endogenous signaling pathways. Toxins. 2020;12:1-26.

35. Rigoni M, Paoli M, Milanesi E, Caccin P, Rasola A, Bernardi P, et al. Snake phospholipase A2 neurotoxins enter neurons, bind specifically to mitochondria, and open their transition pores. J Biol Chem. 2008:283:34013-20.

36. Paoli M, Rigoni M, Koster G, Rossetto O, Montecucco C, Postle AD. Mass spectrometry analysis of the phospholipase A2 activity of snake pre-synaptic neurotoxins in cultured neurons. J Neurochem. 2009;111:737-44.

37. de Silva HA, Ryan NM, de Silva HJ. Adverse reactions to snake antivenom, and their prevention and treatment. Br J Clin Pharmacol. 2016;81:446-52.

38. Sapan CV, Lundblad RL, Price NC, Boulevarde C, Raton B, Healthcare B, et al. Colorimetric protein assay techniques. Biotechnol Appl Biochem. 1999;29:99-108.

\section{Publisher's Note}

Springer Nature remains neutral with regard to jurisdictional claims in published maps and institutional affiliations.
Ready to submit your research? Choose BMC and benefit from:

- fast, convenient online submission

- thorough peer review by experienced researchers in your field

- rapid publication on acceptance

- support for research data, including large and complex data types

- gold Open Access which fosters wider collaboration and increased citations

- maximum visibility for your research: over 100M website views per year

At BMC, research is always in progress.

Learn more biomedcentral.com/submissions 